British \& Irish Botany 3(3): 349-361, 2021

\title{
Recording Persicaria maculosa and P. lapathifolia (Polygonaceae)
}

\author{
Michael Wilcox \\ Bradford, West Yorkshire, UK
}

\section{Corresponding author: michaelpw22@hotmail.com}

This pdf constitutes the Version of Record published on $16^{\text {th }}$ September 2021

\begin{abstract}
Persicaria maculosa Gray (Redshank) is a distinct species which can be distinguished from all forms of $P$. lapathifolia (L.) Delarbe (Pale Persicaria) based on the outer tepal veins. The recording and identification of these two taxa can be clouded by colour variation (especially in the latter species) and due to varied treatments in different works or Floras. This paper describes ways to separate the two species and gives details of the various treatments in order for others to decide which taxonomic work should be followed. It suggests that there is a greater need for further morphological and or molecular studies for this complex group in order to form a consensus. Hybrids may occur but none has been confirmed by scientific methods. It may be that most of these taxa (especially in P. lapathifolia s.l.) are recognizable as forms or varieties, and this is also suggested (informally at present) by the author below, until further work clarifies the situation.
\end{abstract}

Keywords: tepal veins; taxonomy; colour variation; subspecies; hybridisation

\section{Introduction}

The traditional characters of the two species Persicaria maculosa Gray (Redshank) and $P$. lapathifolia (L.) Delarbe (Pale Persicaria) generally hold true and they are quite distinct taxa. The two species have been variably split by some authors. This has clouded the taxonomy of the two, particularly P. lapathifolia. The descriptions and various taxonomies are shown below to allow other workers to pursue the topic in more detail.

\section{Persicaria maculosa Morphology}

The flowers vary from dull whitish pink to bright pink or reddish pink flowers (Figs. $1 a-c)$ (some can look whitish when open). P. maculosa is very common in various open habitats. It more or less has eglandular inflorescences (but see Sell \& Murrell [2018] below). The seeds (achenes) can be with few to many that are more distinctly 3-angled (trigonous) but often mostly biconvex to plano-convex and they are relatively shiny and blackish (Figs. 4, 5; see also Stace, 2019). The three main veins in the outer tepals are branched; the branching comes from the side of the main veins, and they are more or less forward pointing - Fig. 1d; this is diagnostic compared to all forms of $P$. lapathifolia (but see Wisskirchen key below). 
In the field the lack of any glands in the inflorescence can be difficult to ascertain with a $\times 10$ lens. However, a useful tip is that the inner (abaxial) tepal of a number of flowers is often 'humped' (bluntly keeled) (see Fig. 1b-c), making the whole flower somewhat more trigonous. This may be a modification to accommodate any achenes that are bluntly trigonous, but may also be, in part, to accommodate the $5^{\text {th }}$ tepal as not all 'humped' flowers have trigonous achenes. $P$. maculosa often has 5 tepals, two outer and 3 inner, with one of the latter tucked behind the abaxial tepal (i.e. not usually visible in the field). The 'humped' abaxial tepals do not (or very rarely) occur in P. lapathifolia s.l., most flowers being usually relatively flat to the (slightly concave) achene. There are, however, simpler ways to separate the two taxa at the species level.

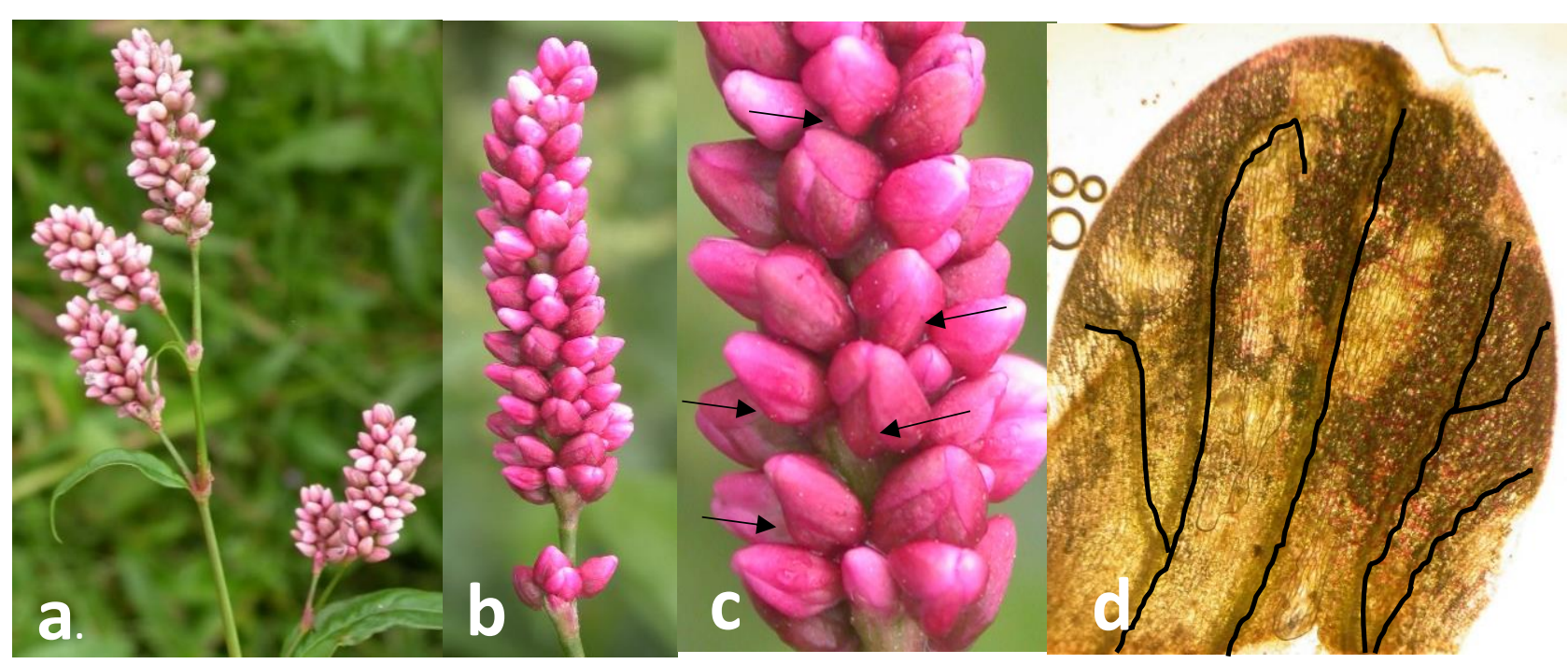

Figure 1. Persicaria maculosa. a) Pale pink flowered inflorescence; b) Deep reddish pink flowers; c) Showing the 'humped' (keeled) inner abaxial (facing away from rhachis) tepals (black arrows - see text); d) The 3 main veins of an outer tepal, with forward pointing branches along their length (black lines drawn on for clarity as the veins are much weaker in this species than the thicker veins in the $P$. lapathifolia taxa).

The leaves of $P$. maculosa (like $P$. lapathifolia s.l.) have green pits on the underside (punctulate). However, in this species any gland or tubercle, as described in Sell \& Murrell (2018), is often colourless or barely a dull whitish colour and very obscure (i.e. not with a distinct amber-yellow gland in the pit) so it appears that only greenish pits occur on the underside (which can be somewhat obscure). $P$. lapathifolia has distinct (bright) yellow or amber shiny glands in the pits. Even if the glands have collapsed they look shiny in and around the pits. This means these two taxa should even be separable vegetatively except (usually earlier in the season) where the pits/glands are obscured by dense white hairs on the underside, especially in $P$. lapathifolia (and 'nodosalike' plants) but these hairs often wear off later in the season and seem to be more common in damp habitats. Plants can also have sparse to scattered frequent short hairs or none. They appear to be of little taxonomic consequence (Akeroyd, 2014). 


\section{Taxonomy}

The treatment in Stace (2019) is the most simple. However, $P$. maculosa is split further in Sell \& Murrell (2018) and this seems to confuse the issue, (see the latter reference for the authorities used).

$\boldsymbol{P}$. maculosa is given with 2 subspecies, one of which has three varieties. The taxa in Sell \& Murrell (2018) are:

P. maculosa subsp. maculosa: with three varieties, (all three with peduncles and rachis without sessile glands and/or glandular hairs):

Var. ruderalis: inflorescence dense or with flowers not or hardly overlapping to 3 $\mathrm{cm}$ long, decumbent to prostrate to $25 \mathrm{~cm}$, with leaves less than $1.5 \mathrm{~cm}$.

Var. maculosa: inflorescence dense to $5 \mathrm{~cm}$, ascending to erect to $60 \mathrm{~cm}$, single but branched from the base, leaves $3-9 \times 1-3 \mathrm{~cm}$.

Var. biformis: inflorescence dense to $5 \mathrm{~cm}$, ascending to erect to $100 \mathrm{~cm}$, branched mainly above and less divaricate, leaves $6-15 \times 0.7-4 \mathrm{~cm}$.

P. maculosa subsp. hirticaulis: inflorescence dense; peduncles and rachis with more or less simple eglandular hairs as well as glandular hairs.

Note that $P$. maculosa subsp. hirticaulis is described as having glandular hairs as well as non-glandular hairs; therefore this could be confused with taxa in $P$. lapathifolia s.I. Any plants with glands in the P. maculosa group (Akeroyd, 2014; Sell \& Murrell, 2018) would need the outer tepal veins checked as illustrated in Fig. 1d and 2 d. $P$. maculosa can have a few glands on occasion and this may be a slightly variable character in this species (and the genus as a whole). See under $P$. lapathifolia for variation.

\section{Persicaria lapathifolia s.l.}

Morphology

This is the more confused of the two species with conflicting treatments clouding the issue. While some forms appear distinct there seems to be variation even in the same plants. Plants with dull pink or pink to reddish pink flowers can easily be confused with forms of $P$. maculosa (and see note on $P$. glabra below). Often $P$. lapathifolia stands out only when it has greenish-white or all pure white flowers and like $P$. maculosa they are usually in a more or less oblong cylindrical spike (Fig. 2) but can have shorter rounder inflorescences. The plants that have rather dull pink to dull reddish pink flowers but with narrow inflorescences and smaller achenes, have been referred to (rightly or wrongly) as 'subsp. nodosa' by some but not by others (see Fig. 3 and comments on subsp. mesomorpha below), the characters of any such taxon seem to be included in various forms of $P$. lapathifolia s.l. in different treatments.

The $P$. lapathifolia aggregate has yellowish glands at least in the inflorescence and seeds (achenes) that are biconcave to plano-concave (Figs. 4 and 5), rarely with any distinctly 3-angled achenes (Stace, 2019). The outer tepal veins are very distinct and not like those of $P$. maculosa, (Fig. 2d) and are diagnostic for all (?) forms of this taxon, (though see Wisskirchen key below).

Complications arise as there are plants that have been known as $P$. lapathifolia subsp. nodosa, which have pink to reddish flowers (Fig. 3) and very small achenes (Figs. 4 and 5) assuming this is accepted as a taxon. The name 'nodosa' is problematic as different Floras treat these types differently. In Sell \& Murrell (2018) 
it seems to refer to plants with 'dirty' pink flowers and similar to those with greenishwhite flowers, and is included in those with the larger achene type (as in left-hand image in Fig. 4). There is no mention of the plants with the small achenes, i.e. no distinction between them. Based on the tepal veins all these 'nodosa' types belong to P. lapathifolia s.l., as in Fig. 2d. Previously, it was known as a species, Persicaria nodosa and other names were combined under Polygonum by Akeroyd (2014) (see below), Sell \& Murrell (2018) and Stace (2019).

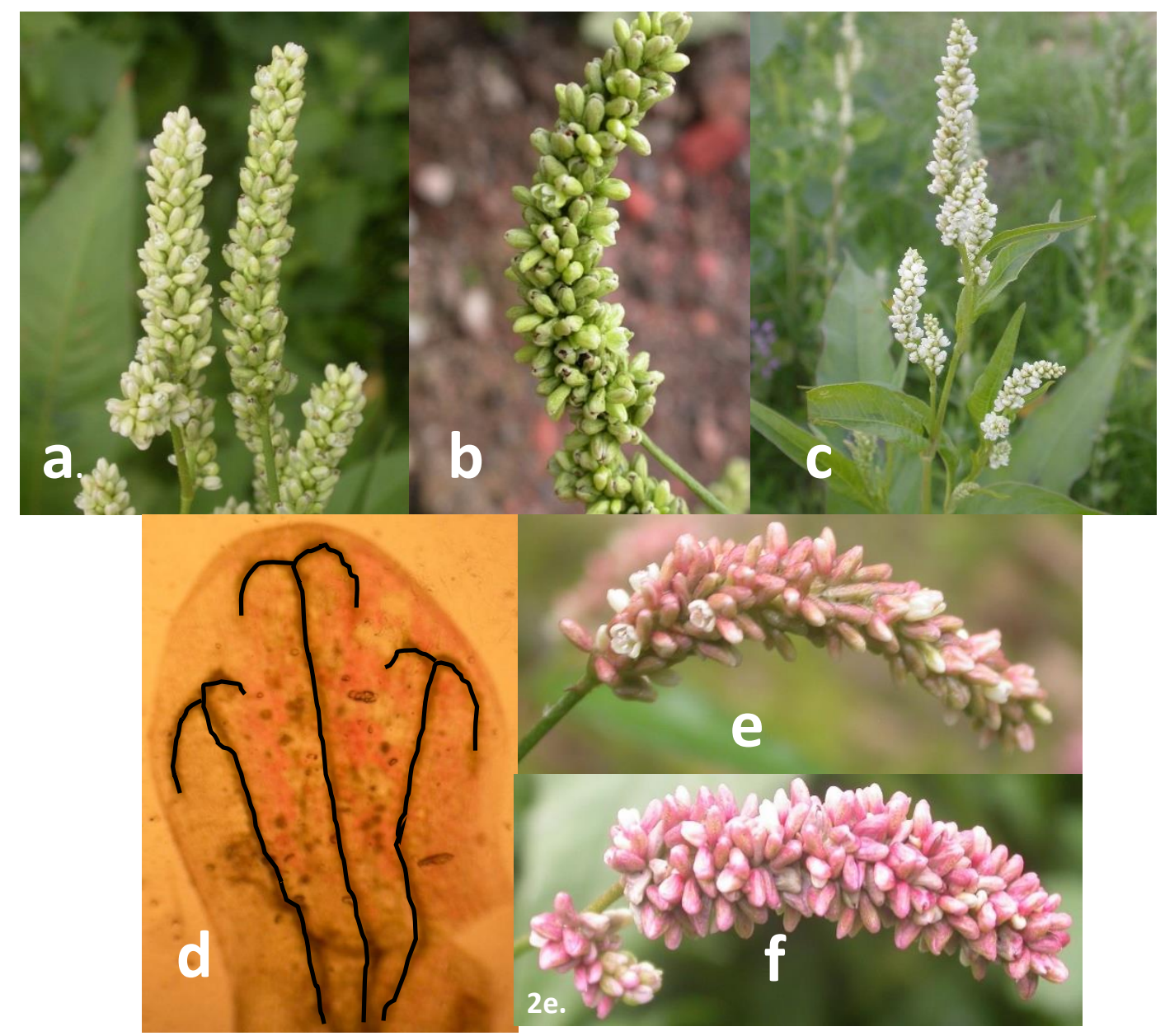

Figure 2. Variants in Persicaria lapathifolia subsp. lapathifolia: a) Greenish-white flowered inflorescences; b) Even more greenish inflorescence ('f. or var. viridiflora' - or within subsp. pallida); c) Pure white flowered inflorescence ('f. or var. 'alba' or 'pallida' - or within subsp. pallida); d) Outer tepal veins, 3 veins branched (bifurcate) at the tip only (very distinctive anchor shape) (black lines drawn on for clarity); $e$ and $f$ ) forms/variants of subsp. lapathifolia (f. or var. lapathifolia) with dull 'dirty' pink flowers (e) and stronger deep-pink flowers (f).

The 'nodosa' type plants can be very common especially around lakes and reservoirs, for example in the right conditions it was frequent at Fewston Reservoir in v.c.64 at one time. These plants have very narrow, dull pink to reddish-pink glandular inflorescences (Fig. 3) and often (at least early in the season) the leaves have dense white (appressed) hairs below. The three outer tepal veins are identical with those of $P$. lapathifolia s.l. and thus it seems to clearly belong to this taxon rather than being a putative hybrid. The narrow inflorescences are generally due to 
the very small achenes (Fig. 4, middle; Fig. 5, Row 1), which are also similar in shape to the achenes for all taxa in P. lapathifolia s.l., i.e. they are biconcave, i.e. with a dimple in the middle (Fig. 4, left). In Britain (in my experience) they always appear to be these dull pink to reddish-pink flowered plants. While in need of further investigation, it was noted that the distinct glands on the underside of the leaves were a bright solid (dried?) golden yellow in 'nodosa', but it is not known if this is related to the hair covering (drying them out) or environmentally induced, or if it is consistent in this taxon only.

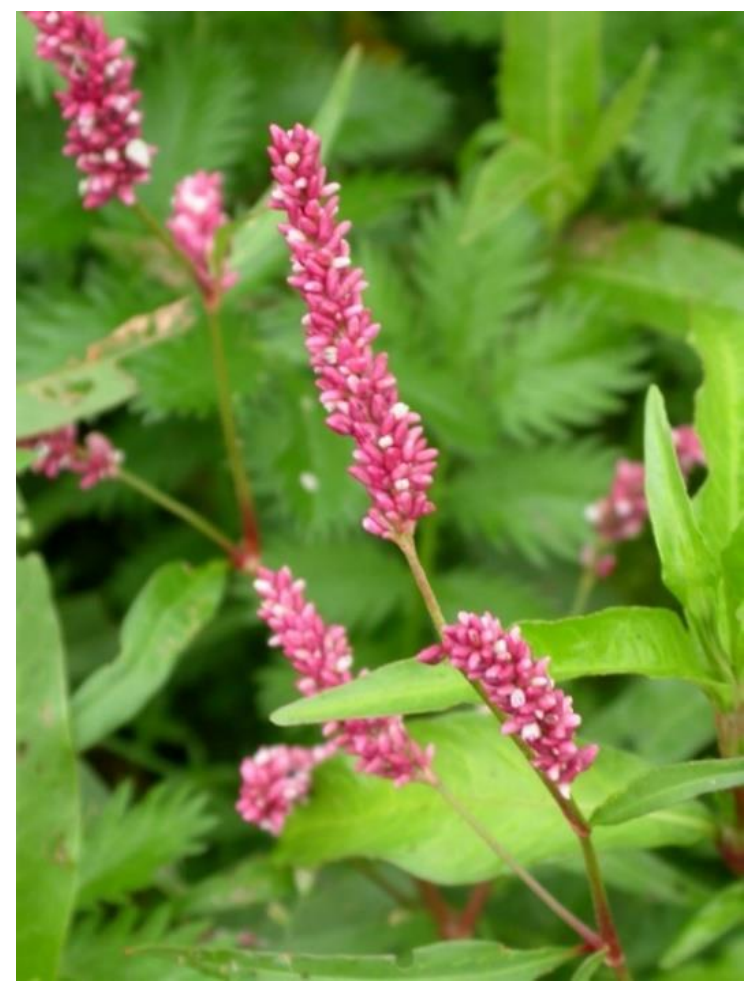

Figure 3. Persicaria lapathifolia 'subsp. nodosa'. Note the long narrow (skinny) inflorescences due to the small achenes (see Fig. 4). Dull pink to mainly strong reddish-pink flowers seen in UK so far.

These reddish-pink flowered plants with narrow inflorescences and the small achenes, and the dull 'dirty' pink flowered plants with normal inflorescence and larger achene sizes could easily be mis-recorded for $P$. maculosa based on flower colour alone. However, the outer tepal veins will separate them from all $P$. maculosa and usually if they have glands on the flowers and peduncles they should belong to P. lapathifolia (but see P. maculosa subsp. hirticaulis in Sell \& Murrell (2018) which needs more investigation). The golden or yellow/amber shiny glands on the underside of the leaves should occur in all forms of $P$. lapathifolia (where they are not obscured by hairs). If present the black, shiny convex achenes of $P$. maculosa are different to those of the biconcave (dimpled) achenes (not usually as black) of $P$. lapathifolia s.l.

\section{Taxonomy}

P. lapathifolia sensu Stace (2019) is treated very differently in Sell \& Murrell (2018). The latter work splits this taxon into two species, and one species has two varieties: 
Persicaria pallida (Pale Persicaria): Stems, peduncles and rachis without simple eglandular hairs, sometimes a few adpressed ones, with sunken (yellowish) sessile or minutely stalked glands or glandular hairs; leaves not acrid, inflorescence erect, perianth segments pale green (the text also mentions that the perianth segments are covered in glands). Flora Nordica treats this taxon as $P$. lapathifolia subsp. pallida, referring to it having usually greenish-white flowers, sometimes or entirely red; with perianth as long as the nut (not constricted above it (Jonsell, 2001). Wisskirchen (1995) treats plants with greenish-white flowers as subsp. pallida.

Persicaria lapathifolia (Red Persicaria): Key as for $P$. pallida except; perianth segments dirty pink (and text says perianth segments with golden glands). Sell \& Murrell (2018) include two varieties:

Var. lapathifolia: stems to $80 \mathrm{~cm}$, leaves lanceolate, ovate or elliptical, with short adpressed simple eglandular hairs and yellow punctate glands beneath. Perianth dirty pink with numerous sessile glands (glands on peduncles as well).

Var. salicifolia: leaves lanceolate, whitish and densely arachnoid hairy beneath. Perianth dirty pink with numerous sessile glands (glands on peduncles as well).

Thus, the main feature separating the two varieties is the density of the hairs on the underside of the leaves. The hair covering is likely to vary from plant to plant and also may become less dense later in the season. Due to self-fertilisation, many plants may be clones of their parent so some characters should be stable, but variation is still likely (possibly also from environmental/habitat modification). Some modes of variation may be stable enough to deserve taxonomic recognition but more extensive studies are needed. Colour variation in flowers may not be a genetically stable character (see below).

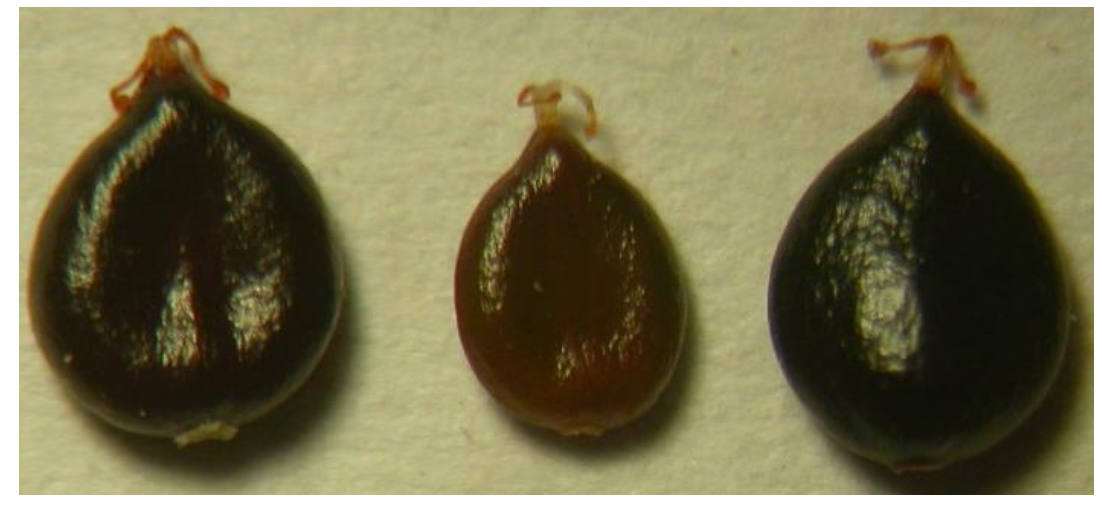

Figure 4. Close up of achenes. Left: $P$. lapathifolia s.l.; middle: $P$. lapathifolia subsp. nodosa' with achenes c. 1/3 smaller overall; these two are both

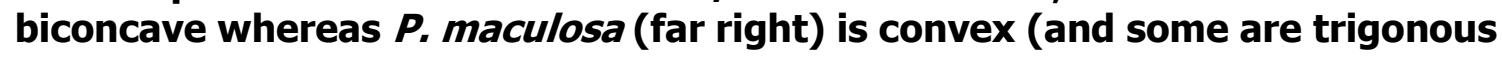
achenes, see Fig. 5).

Jonsell, (2001) describes $P$. lapathifolia subsp. lapathifolia as having fairly slender, pointed inflorescences and flowers usually red sometimes greenish white. The perianth is said to be usually constricted in to a beak just above the nut (achene). This would for the most part describe the slender plants we have in Britain (Fig. 3) of the 'nodosa' type; but it does not describe either of the varieties of $P$. lapathifolia in Sell \& Murrell (2018) and I have not seen pale- to white-flowered 
plants of 'nodosa' in Britain, though they would clearly be possible. Flora Nordica (Jonsell, 2001) also mentions, under $P$. lapathifolia subsp. lapathifolia, 'Polygonum lapathifolium subsp. nodosum var. scanicum'. This is described as being of sea shores, 'procumbent to decumbent, with richly branched stems, small leaves with wavy margins, shortly attenuate base and long tapering apex'. The authors suggest it may be modified by the habitat and that it should not be recognised taxonomically, but see Wisskirchen's subsp. brittingeri below which has more or less rounded leaves and is often decumbent.

It is clear that Flora Nordica (Jonsell 2001) and Wisskirchen (1995) include any subsp. 'nodosa' type plants (as I described here from Britain) within $P$. lapathifolia subsp. lapathifolia, suggesting a more variable plant.

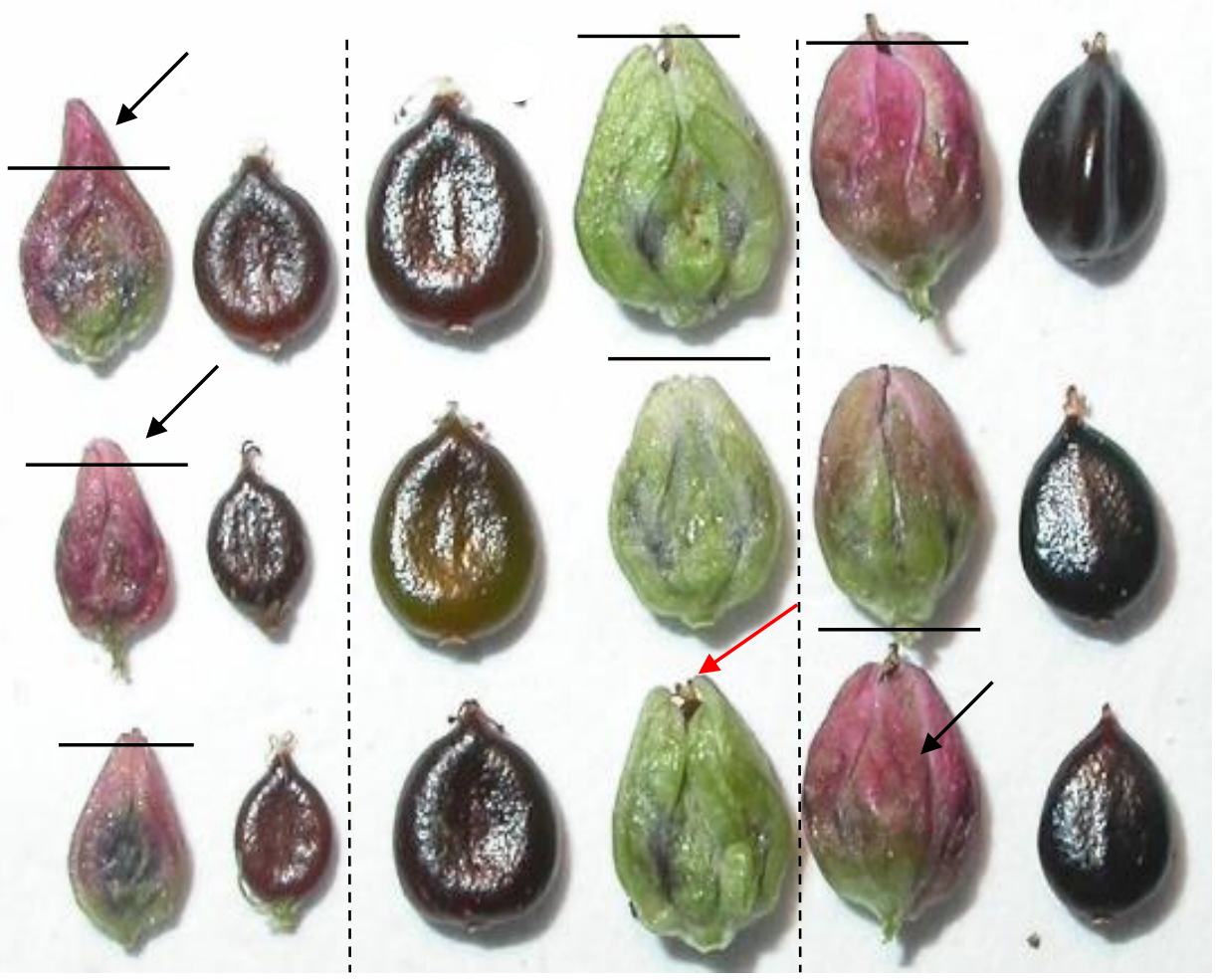

Figure 5. Flowers and achenes of three Persicaria taxa. Left: Persicaria lapathifolia 'subsp. nodosa'; note the distinct 'beak' of the tepals (black arrows) and the achene (and tip of the style) is (always?) shorter than the tepals (see horizontal black lines). Centre: $P$. lapathifolia 'subsp. lapathifolia' with the achene \pm filling the tepals and at least the style being visible at the apex when parted (see bottom flower, red arrow); Right: $P$. maculosa - Top pair shows a trigonous achene (not from the flower shown, see bottom flower in this row showing the keeled inner tepal (with a trigonous nut inside), arrowed) and the other two show the biconvex achenes which fill the tepals. In P. maculosa the style is usually just about equal to or just protruding from the apex of the tepals.

\section{Other taxonomic treatments}

The name $P$. lapathifolia subsp. nodosa (Pers.) A. Löve can be found on the International Plant Names Index (IPNI) (https://www.ipni.org/n/190820-2). However, the names 'nodosum' and 'nodosa' are only included in synonymy in Sell \& 
Murrell (2018) and Stace (2019). The main issue with subsp. nodosa in Sell \& Murrell (2018) is that it does not describe the plants that have narrow inflorescences, (more bright) reddish-pink flowers and small achenes. However, Flora Nordica does seem to include these in $P$. lapathifolia subsp. lapathifolia with a wider circumscription. Sell \& Murrell (2018) describe their $P$. lapathifolia var. lapathifolia as a plant similar to the white to greenish-white flowered plant, in that it has typical more or less oblongcylindrical spikes (with normal sized achenes) but with dull ('dirty') pink flowers. The plants with dull 'dirty' pink flowers can be found (often I have seen them on waste ground or more nutrient rich areas - but others can be found in the same places). Akeroyd (2014) gives a description of a plant once called 'Polygonum nodosum' when it was in that genus. However, it seems confused as it says (admittedly from second-hand information), that the achenes have 'shoulders' (illustrated therein). Plants here (and as in Flora Nordica) are what should be referred to as the 'nodosa' type plants regardless of any taxonomic recognition (Fig. 4 [middle]) and Fig. 5 Group 1).

In a rather obscure paper, (Mosaferi et al., 2010) report and describe Persicaria lapathifolia subsp. nodosa as new to Iran. They give information about glands on the leaf underside and cells in the tepals. However, I do not think the cell differences work. These authors may be confusing the two different layers of epidermis in the tepals. It is an aspect that would need looking into. However, these plants fit the description of what I would think of as subsp. nodosa whether the nomenclature is correct or not.

The detailed morphological work by Wisskirchen $(1991,1995)$ was published in German and is perhaps not widely known. He concluded there are at least four subspecies in $P$. lapathifolia. These subspecies included subsp. pallida (those with greenish-white or white flowers); subsp. lapathifolia (in which any 'nodosa-like' plants are included according to Wisskirchen (pers. comm. 2021) (but see below); subsp. leptoclada and subsp. brittingeri (which may be a distinct form that has rather rounded leaves with distinct black blotches and is decumbent-procumbent ascending (Fig. 6). The latter may occur in Britain according to images seen on Herbaria United (R. Wisskirchen, pers. comm. 2021). Details and the main key information are given here (kindly translated from German by Prof. R. Wisskirchen):

Persicaria lapathifolia (L.) Delabre - [Polygonum lapathifolium L.] Red Persicaria. $1 \quad$ Plants mostly with significant red colour content (anthocyanin); stems therefore often flushed red and/or red dotted; main stem usually with 14-30 or more nodes (except for small plants) and therefore with relatively short internodes. Leaves (leaf-blades) purer green, usually becoming reddish with age, leaf spot (anthocyanin) mostly very clear, but occasionally missing. Apical inflorescences (except in small plants) loosely arranged above the last clear leaf, with 2 to 5 markedly stalked spikes, sometimes even arranged panicle-like. Spikes quite slender (about 6-8 mm diameter when achenes are ripe), often more or less overhanging [arching-drooping?]. Inflorescence and flowers often only weakly glandular. Perianth after flowering white or pink (to red), not becoming clearly green, usually completely enveloping the ripe nut. Perianth nerves (of outer tepals) protruding during ripening and with a well expressed anchor-hook shape structure. Nuts mostly oval, rarely round, clearly with a rounded base, between 1.8 and $2.3 \mathrm{~mm}$ long excl. style. 
Flowering period: July-October. Moist places: plants of banks, ditches, damp fields etc... 2

2 Plant usually ascending to upright, under favourable conditions quite tall (up to about $1.5 \mathrm{~m}$ ), leaf-blades lanceolate, about 3 to 6 times as long as wide: subsp. lapathifolia - [subsp. lapathifolium] Red Persicaria s. str.

2 Plant mostly prostrate or slightly ascending, or almost upright, rarely (only in dense stands) high-growing. Leaf-blades short ovate-lanceolate, ovate, oval or round, with the lower ones not more than 2 times as long as wide : subsp.

brittingeri (Opiz) Soó - [ssp. brittingeri (Opiz)] Soó. River Persicaria.

1 Plants with little or no anthocyanin content; stems therefore predominantly green, less often slightly flushed reddish; with usually 7-14 nodes (less in small plants) and relatively long internodes, not high-growing. Leaves (leaf-blades) more grey-green, becoming yellowish with age, leaf spot blurred or missing. Final inflorescences compact, with usually only 1 to 2 spikes above the last clear leaf - the lateral ones often reduced and unstalked. The spikes are thick-cylindrical (at the time of ripening approx. 8-10 mm diameter) and usually straight or only slightly bent. Inflorescence and flowers often more glandular. Perianth after flowering due to chlorophyll development clearly greening (rarely additionally a little reddish), often not completely enveloping the ripe achene. Perianth nerves (of outer tepals) not protruding in part of the fruit and/or with disturbed (less defined) anchor-hook shape structure. Fruits roundish, with a slightly rounded to straight base, 2.3 to 3.0 $\mathrm{mm}$ long excl. style. Flowering time: June-August. Mainly plants of the fields, also ruderal, rare in dams and at small rivers (= crop taxa) ... 3

3 Internodes long, but not conspicuously long and slender, the often long lateral branches sparse, protruding. Leaves more wide-lanceolate. Ripe fruits falling off. Perianth nerves partially protruding...subsp. pallida (With.) A. Löve [ssp. pallidum (With.) Fries] Pale Persicaria

3 Internodes remarkably long and slender, the ascending lateral branches often longer than the main stem and above it, or plants completely unbranched. Leaves more narrow-lanceolate. Perigon nerves not protruding and usually anastomosing. Perigon often much shorter than the nut. Ripe fruits do not drop (fruit stalks below the fruit usually unarticulated or inoperable)...subsp. leptoclada (Dans.) Wissk. [ssp. leptocladum Dans.] Flax Persicaria.

\section{Questionable and little-known taxa.}

Wisskirchen gives details about Danser's 'Polygonum mesomorphum' and despite concerns, he considers that it could be accepted at the subspecies level ( $R$. Wisskirchen, pers. comm. 2021). Information from Danser (1932) characterises the taxon as follows: "Whole plant pale or grey-green to dark- or reddish-green, very different, but under normal conditions 1-2 feet tall, the stems usually ascending to upright, the leaves linear lanceolate to ovate-lanceolate, the spike-like inflorescences not thick due to the rather small fruits, but densely cylindrical, usually clustered to larger inflorescences. Perianth white during flowering with green base, remaining white or getting green after flowering, or more or less red overflowing, to varying degrees with glands. Fruit usually 2-2.5 mm long and about as wide. Felt [hairs] in dry locations usually abundantly developed on the lower side of the leaves, but on the upper sides of the leaves, the ochrea and the stems usually not developed or only weakly" (Danser 1932) (translated version: Wisskirchen, pers. comm. 2021). 


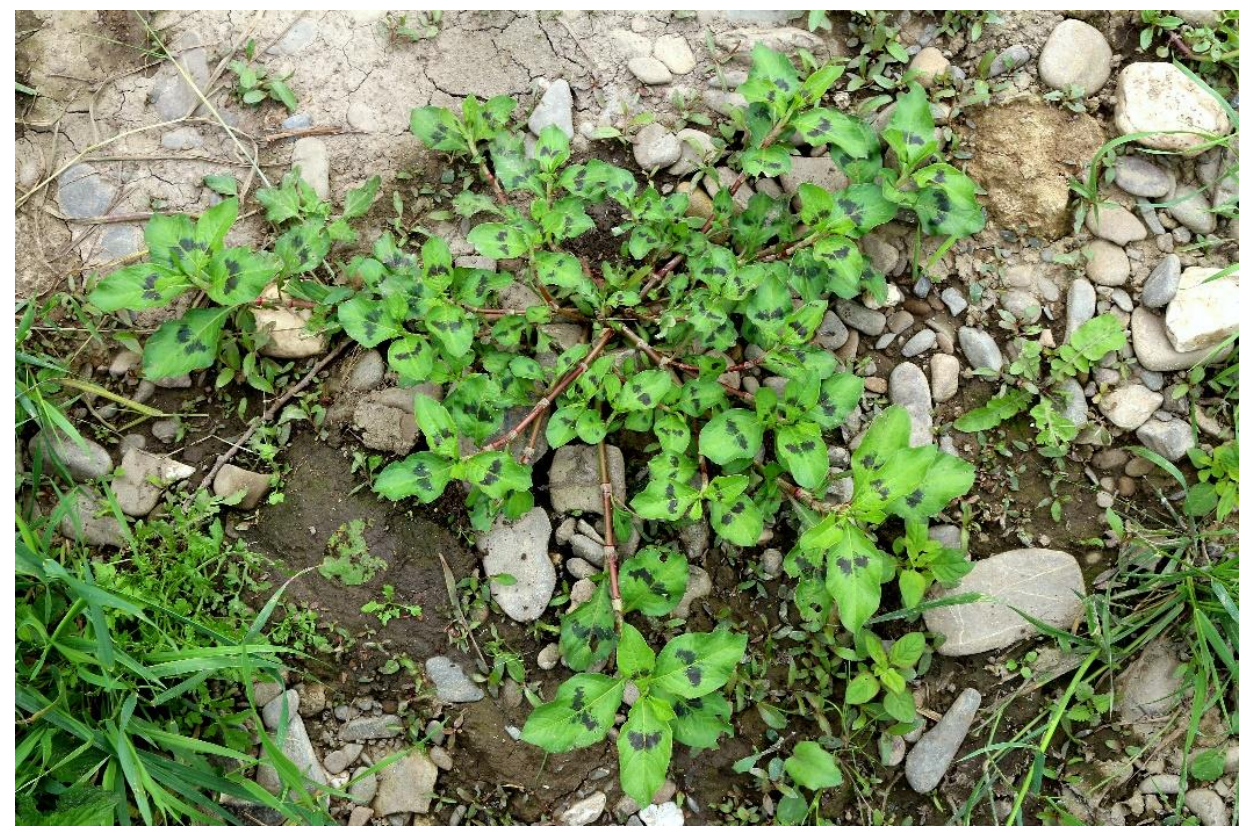

Figure 6. Persicaria lapathifolia subsp. brittingeri $\odot$ Rolf Wisskirchen

Prof Wisskirchen provides his assessment as: "Polygonum mesomorphum Judging from the knowledge of Danser's 'Polygonum mesomorphum'original material (L, GB) I could not decide whether to recognize it as a true taxon and to include it in the key. It was not possible to include it so it would key out fully." Essentially, it characterizes a transition between the two main ecotypes - in this case mainly between the subsp. lapathifolia and subsp. pallida. Such plants can be found in damp or flooded fields and in reservoirs, sometimes also in sewage ponds or at ruderal sites. The only tangible characteristic is a fruit size of approx. 2-2.5 mm (as long as wide), which stands between the two main types. Since the character of fruit size is not really reliable (Wisskirchen 1991) and the overlap here is quite large, it seems to me that the taxon 'mesomorphum' is too weakly characterised to be able to exist independently. However, a final evaluation is still pending. In a later email he suggested it could be a recognisable taxon

To the present author, this description suggests the small-fruited form also known as subsp. nodosa. Wisskirchen (pers. comm. 2021) rejected this suggestion and considers it is mere fantasy to consider the plants I know as 'nodosa' as a distinct taxon at any rank, yet he now considers Danser's description to be a possible recognisable taxon. There could be something lost in translation but it is for those with greater knowledge to accept these taxa or not. The work of Wisskirchen has been reiterated here as it is the most detailed study of the taxa to date and due to the detailed examination of these taxa, the subspecies he advocates may become acceptable.

\section{A note on Persicaria glabra}

Persicaria glabra (Willd.) M. Gómez (Hairless Persicaria, see Akeroyd, 2014) was recorded in 2019 from Somerset (Crouch \& Akeroyd, 2020) and illustrated. In Akeroyd (2014) it is placed close to $P$. lapathifolia suggesting the outer tepal veins are the same and similar to the pink to reddish flowered forms of this species. True 
P. glabra is a rhizomatous perennial with completely glabrous leaves and more importantly it does not have the anchor-shaped veins that belong to $P$. lapathifolia s.l. (see Cialdella \& Brandbyge, 2001; and e-Flora North America). An examination of an inflorescence and a leaf from the Somerset plant, said to be annual (courtesy of Dr Helena Crouch), clearly showed that it had outer tepals with anchor-shaped veins. Thus, being annual with these tepal veins, it belongs to $P$. lapathifolia. The leaf and inflorescence was sent to Prof R. Wisskirchen, and he agreed that it was $P$. lapathifolia, and in his scheme belonged to subsp. lapathifolia.

\section{Conclusions}

For a possible consensus approach to these taxa, they could be split as follows (where a variety (var.) is given this could even be reduced to forma (f.); or for the time being if recording for the BSBI database, place the colour type/name in the comments section as they are not at present meant to be validly published names):

P. maculosa: Outer tepals veins 3, with 1-2 ascending thin forward pointing branches along the length; leaves with green (sometimes obscure) pits on the underside (without yellow or amber-shiny glands); achenes, blackish, \pm shiny mostly biconvex mixed with a few trigonous ones; (the latter dorsally (adaxially) flat but ventrally (abaxially) trigonous among the dorsoventrally compressed ones (see Fig. 1 and Fig. 5). Further studies may reveal varieties or forms as in Sell \& Murrell (2018).

P. lapathifolia s.l.: Outer tepal veins 3, stout, branched (bifurcate) 'anchor-shaped' only at the apex (though see Wisskirchen's ssp. leptoclada and ssp. pallida above). Distinct, often shiny (amber, becoming yellow when dry), glands in the pits on the underside of the leaves (sometimes obscured by hairs). Glands at least on peduncles and perianths; inflorescence ovate to mainly oblong-cylindrical or narrow and apparently pointed; flowers dull pink or mixed pink/greenish-white, distinctly reddish, or, all greenish or all white flowers only; achenes biconcave to planoconcave (dimpled), rarely any trigonous so most if not all fruiting flowers flat (dorsoventrally compressed); achene and or style at least equal to the apex of the outer tepals, filling the tepals and not forming a beak (constriction); or achene not filling the perianth and forming a beak (constriction) of the outer tepals. All ruderal and or damp habitats.

Until more studies have been carried out (at least on British material), one informal approach would be to record $P$. lapathifolia as forms or varieties (generally by colour) and some as subspecies using the following artificial key:

1. Inflorescence roundish to more usually oblong-cylindrical; flowers very dull pink to reddish-pink sometimes mixed with greenish-white flowers; or greenish-white flowers only or pure white only; achene and or style at least equal to or just beyond the apex of the outer tepals, filling the perianth and not forming a (beak) constriction near the apex. P. lapathifolia subsp. lapathifolia

1a. Inflorescence mainly pink-flowered (occasionally mixed with other colours (greenish/white) which maybe on the side away from the light) $P$. lapathifolia subsp. lapathifolia f. lapathifolia (Fig. 2f)

1b. All flowers greenish-white...P. lapathifolia subsp. lapathifolia f. viridiflora [within subsp. pallida] (Fig. 2a, b)

1c. All flowers pure white......P. lapathifolia subsp. lapathifolia f. pallida (or alba?) [within subsp. pallida] (Fig. 2c) 
1. Internodes remarkably long and slender, the ascending lateral branches often longer than the main stem and above it, or plants completely unbranched. Leaves more narrow-lanceolate. Perianth nerves not protruding and usually anastomosing. Perianth often much shorter than the nut. Ripe fruits do not drop (fruit stalks below the fruit usually unarticulated or inoperable) .... . lapathifolia subsp. leptoclada [subsp. leptocladum] (Flax Persicaria)

1. Not as above. Either prostrate to slightly ascending with ovate-lanceolate, oval or rounded leaves, achene filling the perianth; or erect with tepals forming a beak (constriction) due to achenes not filling the perianth

2. Plant mostly prostrate or slightly ascending, (only when in dense stands is it almost upright, but not growing tall). Leaf-blades short ovate-lanceolate, ovate, oval or round, with the lower ones not more than 2 times as long as wide...P. lapathifolia subsp. brittingeri (River Persicaria) (Fig. 6).

2. Inflorescence very narrowly-cylindrical (usually due to reduced size of achenes) often pointed at the apex; pale- (a few whitish) mixed with dull-pink to often reddish flowers; achene and or style shorter than the apex of the outer tepals, not filling the perianth and forming a constriction (beak) near the apex...P. lapathifolia subsp. nodosa (?) 'Narrow-spiked Persicaria' (Fig. 3 \& Fig. 5, Group 1) or is it subsp. mesomorpha (?) but this may not be what Wisskirchen regards as this taxon from Danser (1932) (see above)

A simpler option would be to record as Persicaria lapathifolia with variants commented on as follows:

Plants with large achenes filling the perianth:

$P$. lapathifolia (mostly pink, reddish flowers)

$P$. lapathifolia (greenish flowers)

$P$. lapathifolia (all white flowers)

P. lapathifolia (branches longer than main stem, fruit stalk remaining attached, achenes not dropping)

P. lapathifolia (more or less low growing, roundish leaves with large black spot) Plant with small achenes not filling the perianth, beaked outer tepals:

$P$. lapathifolia (narrow spikes with beaked outer tepals and small achenes).

It is worth pointing out that despite the number of hybrids reported or recorded (Akeroyd 2014; Stace et al. 2015) no hybrid has ever been confirmed cytologically or molecularly from the wild. Also, Timson in Stace (1975), (see Stace et al. 2015), stated that any attempts at artificial hybridisation have been unsuccessful. For these mainly annual autogamous (self-fertile) taxa, it is likely to be difficult to confirm a hybrid. However, Parnell \& Simpson (1989) studied populations of Persicaria mitis (Schrank) Assenov and $P$. minor (Huds.) Opiz) (as Polygonum mite Schrank and $P$. minus Huds.) on the shores of Lough Neagh, v.c.H36 in Ireland. They found that (putative) hybrids had a significant reduction in pollen stainability. Under P. lapathifolia, Akeroyd (2014) it states that most (putative) hybrids especially with $P$. maculosa seem to be referable to one or the other parent. It is likely that most species are mainly cleistogamous (pollinated in closed flowers) and therefore hybrids are much less likely. Wisskirchen's 'subsp. leptoclada' description suggests a possible hybrid, but requires more study. Further artificial hybridisation trials are needed, at least between the two 'species' outlined here and material should be 
retained for molecular studies. The studies of Parnell \& Simpson (1989) suggests that hybrids might exist but none have been confirmed.

\section{Acknowledgements}

Particular thanks to Prof Rolf Wisskirchen and Prof C.A. Stace. Also to D. Broughton for the pages from Flora Nordica and Dr Helena Crouch for a sample of the Somerset plant.

\section{References}

Akeroyd, J.R. 2014. Docks and Knotweeds of Britain and Ireland. BSBI Handbook No. 3: London: Botanical Society of Britain \& Ireland.

Cialdella, A.M. \& Brandbyge, J. 2001. Polygonaceae. Flora del Paraguay fasc. 33: 4445. Geneva: Conservatoire et Jardin Botanique de la Ville de Genève.

Crouch, H. \& Akeroyd, J. 2014. Persicaria glabra - a potentially overlooked birdseed alien. Adventives \& Aliens. BSBI News 144: 56-57.

e-Flora of North America. [Accessed, 23.06.2021]. Available at: http://beta.floranorthamerica.org/Persicaria glabra

Mosaferi, S., Keshavarzi, M. \& Amini, T. 2010. Persicaria lapathifolia subsp. nodosa (Polygonaceae) is recorded for the flora of Iran. Iran. J. Bot. 16 (2): 254-257. Tehran.

Parnell, J.A.N. \& Simpson, D.A. 1989. Hybridization between Polygonum mite Schrank, $P$. minus Huds. and $P$. hydropiper L. in Northern Ireland with comments on their distinctions. Watsonia 17: 265-272.

Sell, P. D. \& Murrell, G. 2018. Flora of Great Britain \& Ireland. Vol. 1. Cambridge: Cambridge University Press.

Jonsell, B. (Ed.). 2001. Flora Nordica: Vol. 2. Chenopodiaceae - Fumariaceae. Stockholm: The Bergius Foundation.

Stace, C.A. 1975. Hybridization and the Flora of the British Isles. London: Academic Press.

Stace, C.A., Pearman, D.A. \& Preston, C.D. 2015. Hybrid Flora of the British Is/es. Bristol: Botanical Society of Britain \& Ireland.

Stace, C.A. 2019. New Flora of the British Isles. Middlewood Green, Suffolk; C \& M Floristics.

Wisskirchen, R. 1991. Zur Biologie und Variabilität von Polygonum lapathifolium L. (Contributions to the biology and variation in Polygonum lapathifolium). Flora 185: $267-295$.

Wisskirchen, R. 1995. Zur Bestimmung der Unterarten von Polygonum lapathifolium s.l. Floristische Rundbriefe 29(1): 1-25.

Copyright retained by author(s). Published by BSBI under the terms of the Creative Commons Attribution 4.0 International Public License.

ISSN: $2632-4970$

https://doi.org/10.33928/bib.2021.03.349 